\title{
GENETIC STRUCTURE ACROSS A CONTACT ZONE BETWEEN XEROSPERMOPHILUS GROUND SQUIRRELS IN SOUTHERN CALIFORNIA
}

\author{
Philip Leitner ${ }^{1}$, Jennifer Rippert ${ }^{2}$, and Marjorie D. Matocq ${ }^{2,3}$
}

\begin{abstract}
The Mohave ground squirrel (Xerospermophilus mohavensis) is endemic to the western Mojave Desert of California and is state-listed as Threatened. This species is of conservation concern because of the potential for large-scale renewable energy development within its range. Recent evidence suggests that this threatened species may at least occasionally hybridize with the closely related round-tailed ground squirrel (Xerospermophilus tereticaudus) where the species come into contact. As a result, there is great interest in the distribution of the Mohave ground squirrel, especially where it may come in contact with the round-tailed ground squirrel. One of the least understood portions of the Mohave ground squirrel distribution is around the Hinkley Valley, west of the city of Barstow, where its eastern range limits come into proximity with the round-tailed ground squirrel. To document what is known of the fine-scale distribution of these congeners in this region, we assemble and review all available trapping survey data from this area and combine the field survey data with genetic analyses of recently collected samples. Our evaluation of trapping records confirms that there are no reliable recent reports of Mohave ground squirrels in the Hinkley Valley itself, which has been developed for agriculture. The species appears to be largely restricted to the relatively undisturbed desert habitat west of Hinkley. In contrast, a number of round-tailed ground squirrel records exist for the Hinkley Valley, some dating back to 1977. Using 13 nuclear microsatellite loci from 55 ground squirrel samples collected across this region, we confirm the presence of genetically pure Mohave and round-tailed ground squirrels. However, 3 individuals collected in the Hinkley Valley that were identified as round-tailed ground squirrels on the basis of external characteristics show evidence of Mohave ground squirrel ancestry. In similar fashion, 3 animals from the desert region west of Hinkley were found to have some round-tailed ground squirrel genetic ancestry in spite of external features typical of Mohave ground squirrels. While round-tailed ground squirrels seem to be the dominant species in Hinkley Valley and Mohave ground squirrels seem dominant in the desert environment to the west, hybridization does appear to occur occasionally. Further, when these species hybridize, at least some hybrids are fertile, and backcrossing appears to occur in both parental directions. It is important to investigate this phenomenon more closely to evaluate possible threats to the genetic integrity of the Mohave ground squirrel.
\end{abstract}

Resumen.-La ardilla de Mojave (Xerospermophilus mohavensis) es endémica del oeste del desierto de Mojave en California y está catalogada como una especie “en peligro." Su conservación resulta de interés debido al potencial desarrollo de la energía renovable a gran escala dentro de su rango. Evidencia reciente sugiere que esta especie en peligro podría, ocasionalmente, hibridar con la ardilla de cola redonda (Xerospermophilus tereticaudus) cuando estas especies entran en contacto, ya que están estrechamente relacionadas. Como resultado, existe un gran interés en conocer la distribución de la ardilla de Mojave, especialmente en los lugares donde puede estar en contacto con la ardilla de cola redonda. Una de las áreas de distribución de las ardillas de Mojave menos conocida se encuentra alrededor del Valle de Hinkley, al oeste de la ciudad de Barstow, donde los límites de su rango hacia el este se aproximan a los de la ardilla de cola redonda. Para documentar lo que se conoce sobre la distribución a pequeña escala de estos congéneres en esta región, reunimos y revisamos todos los datos disponibles acerca de los registros de captura en esta área y combinamos estos datos con el análisis genético de muestras colectadas recientemente. Nuestra evaluación de los registros de captura confirma que no hay información reciente y confiable sobre las ardillas de Mojave en el Valle de Hinkley, el cual ha pasado por desarrollo importante debido a la agricultura. La especie parece estar restringida, en su mayoría, al hábitat de desierto relativamente sin disturbio al oeste de Hinkley. En contraste, existen varios registros de ardillas de cola redonda en el Valle de Hinkley, algunos de los cuales datan del año 1977. Utilizando 13 loci de microsatélites nucleares de 55 muestras de ardillas colectadas en toda la región, confirmamos la presencia genética pura de ardillas de Mojave y de cola redonda. Sin embargo, tres individuos colectados en el Valle de Hinkley, identificados como ardillas de cola redonda con base en sus características externas, mostraron ancestría común con ardilla de Mojave. De igual manera, tres animales de la región desértica del oeste de Hinkley tenían alguna ascendencia genética de la ardilla de cola redonda a pesar de poseer las características externas típicas de las ardillas de Mojave. Mientras que las ardillas de cola redonda parecen ser la especie dominante en el Valle de Hinkley y las ardillas de Mojave lo son en el área oeste del desierto, la hibridación parece ocurrir ocasionalmente. Además, cuando estas especies hibridan, algunos híbridos resultan ser fértiles y el retrocruzamiento parece ocurrir en ambas direcciones parentales. Nos parece importante investigar este fenómeno más de cerca para evaluar las posibles amenazas a la integridad genética de la ardilla de Mojave.

\footnotetext{
12 Parkway Court, Orinda, CA 94563

${ }^{2}$ Department of Natural Resources and Environmental Science; Program in Ecology, Evolution, and Conservation Biology, University of Nevada, Reno, NV 89557.

${ }^{3}$ Corresponding author. E-mail: mmatocq@cabnr.unr.edu
} 


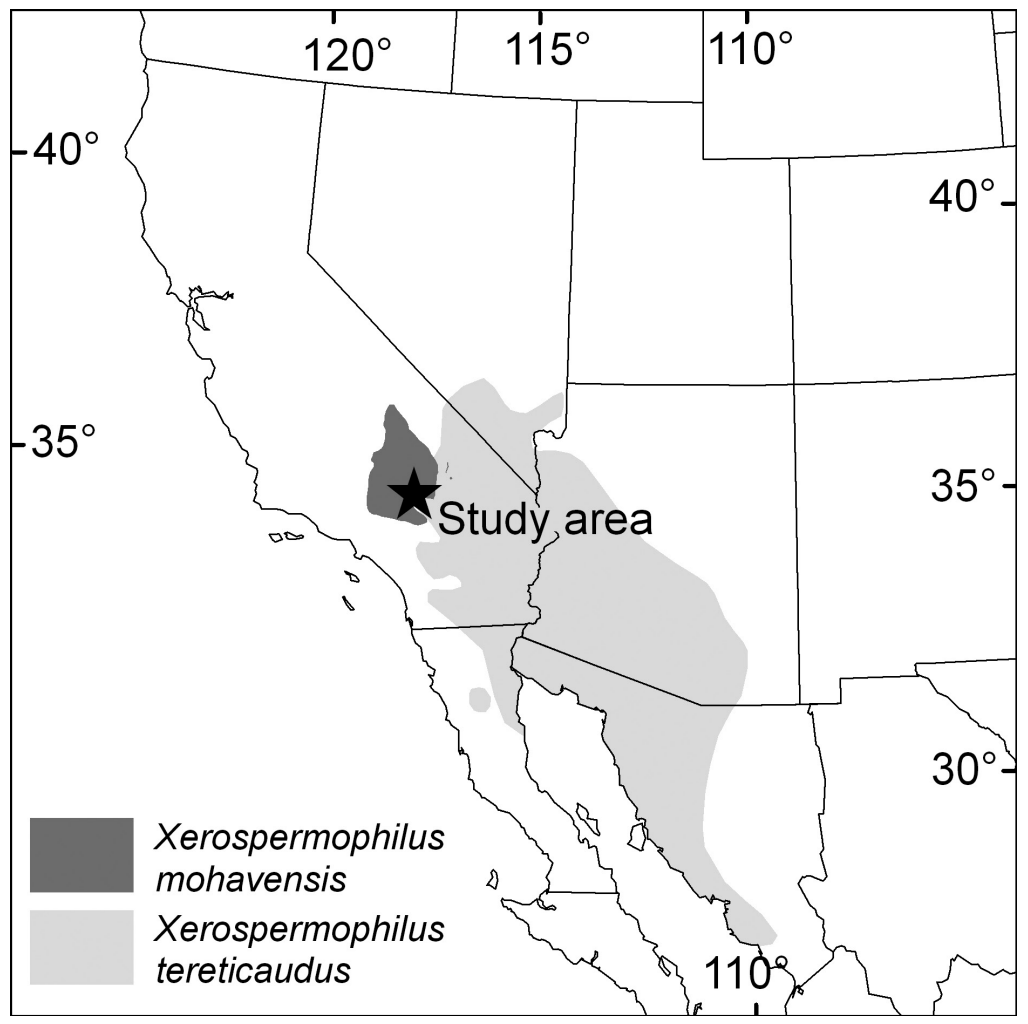

Fig. 1. Distribution of Xerospermophilus mohavensis, the Mohave ground squirrel (dark gray), and Xerospermophilus tereticaudus, the round-tailed ground squirrel (light gray). The study region is indicated with a star.

The Mohave ground squirrel (Xerospermophilus mohavensis) is found only in the western Mojave Desert of California. The species was originally listed as Rare in 1971 under the California Endangered Species Act (CESA). With the reauthorization of CESA in 1984, the species was categorized as Threatened. It is believed to have suffered extensive habitat loss, fragmentation, and degradation resulting from a number of anthropogenic threats including urbanization, agricultural development, livestock grazing, military training, and off-road vehicle use. In 2006 the Bureau of Land Management (BLM) adopted the West Mojave Plan that established development limitations on approximately $1.7 \mathrm{mil}-$ lion acres of BLM-managed lands within the range of the Mohave ground squirrel (BLM 2005). Because of the potential for renewable energy development within its range, the Mohave ground squirrel is of great conservation interest. The current distribution and status of the Mohave ground squirrel has been documented in 2 recent publications (Leitner 2008, 2015).

The Mohave ground squirrel is closely related to the round-tailed ground squirrel (Xerospermophilus tereticaudus), whose distribution ranges from the deserts of eastern California and southern Nevada throughout much of Arizona and south into Mexico (Fig. 1). The 2 species are very similar in external appearance, with the most obvious difference being the shape and length of the tail. While the tail of the Mohave ground squirrel is relatively short and flat, that of the round-tailed ground squirrel is longer and circular in cross section. The Mohave ground squirrel is found only in the western Mojave Desert where winter rainfall predominates, while the roundtailed ground squirrel occupies an extensive range to the east and south that is characterized by hotter and drier conditions, with rainfall primarily in the summer.

It has been assumed for many years that these 2 species are largely allopatric, with their 
geographic ranges meeting but not overlapping. Their contact zone was first described as stretching from Fort Irwin south through the Barstow area, then south along the Mojave River toward Victorville (Wessman 1977, Gustafson 1993), but recent evidence suggests that round-tailed ground squirrels occur some distance west of the Mojave River in the Hinkley Valley. Further, based on genetic analyses, Bell and Matocq (2011) reported that the 2 species occasionally hybridize where their distributions meet. As a result, there is renewed interest in not only documenting the distributional limits of the threatened Mohave ground squirrel throughout its range but, in particular, documenting its fine-scale spatial distribution and genetic interactions where it meets the round-tailed ground squirrel. In order to document the distribution and genetic interactions of these species in a potential area of contact near Barstow and the Hinkley Valley, we assembled decades of trapping survey data from the region and conducted a genetic analysis of recently collected samples. By combining spatial and genetic data, we can begin to identify the potential scope of ecological and evolutionary interactions between these species, which may play an important role in how they will respond to future environmental change.

\section{METHODS \\ Compilation of Ground Squirrel Locality Records}

Ground squirrel locality records were compiled from a number of sources. The primary source of occurrence data for the Mohave ground squirrel was the California Natural Diversity Database (CNDDB), which is maintained by the California Department of Fish and Wildlife as a central repository of information on plants, animals, and natural communities with special status. Additional data sets on Mohave ground squirrel distribution were obtained from museum records, unpublished reports, and consultation with knowledgeable biologists. The CNDDB does not provide data on the round-tailed ground squirrel because it is not a special-status taxon. Locational data for this species were collected from the Natural History Museum of Los Angeles County, the Museum of Vertebrate Zoology (UC Berkeley), and the VertNet data portal (www.vertnet.org).
Additional information was obtained from unpublished reports and consulting biologists. A final important source was the 1998-2012 database of occurrence records for both species maintained by one of the authors (PL).

\section{Genetic Analysis}

SAMPLING.-A total of 55 samples were available for the focal study area, which included the Hinkley Valley and desert habitats out to about $10 \mathrm{~km}$ (6 miles) west of Hinkley. These samples included a set of 14 specimens collected in the Hinkley Valley in 2012 and 2013 (Vanherweg 2012, 2013). Other samples were derived from field studies conducted within the region from 2006 to 2014. In order to place the focal study area into the context of species and population diversity of Mohave ground squirrels and round-tailed ground squirrels of the region, we augmented these samples with an additional 72 specimens previously genotyped in Bell and Matocq (2011).

Nuclear Microsatellite Analyses.-For all 127 samples, we amplified 13 microsatellite loci with the following primer sets: GS14 (Stevens et al. 1997, designed for Spermophilus columbianus); IGS 110b and IGS 6 (May et al. 1997, designed for Spermophilus brunneus); B126 (Garner et al. 2005, designed for S. brunneus); and loci developed for $X$. mohavensis, namely XmohC109, XmohC114, XmohC9, XmohB3, XmohC10, XmohD116, XmohA114, XmohB108, and XmohB118 (Bell and Matocq 2010). We carried out DNA amplification in $10 \mu \mathrm{L}$ reactions that included $1 \mu \mathrm{M}$ of each primer (forward primer fluorescently labeled), $5 \mu \mathrm{L}$ of Reddy Mix (0.25 units of Taq polymerase, $75 \mathrm{mM}$ Tris-HCl [pH 8.8], $20 \mathrm{mM}$ $[\mathrm{NH}]_{4} \mathrm{SO}_{4}, 1.5 \mathrm{mM} \mathrm{MgCl} 2,0.01 \%[\mathrm{v} / \mathrm{v}]$ Tween 20 , and $200 \mu \mathrm{M}$ of each dNTP; ABgene), and $3.0 \mu \mathrm{L}$ of $\mathrm{H}_{2} \mathrm{O}$. The settings on a PTC-200 thermocycler (MJ Research) were the following: initial denaturation temperature of $94{ }^{\circ} \mathrm{C}$ for $10 \mathrm{~min}$, then 40 cycles of $93{ }^{\circ} \mathrm{C}$ for $30 \mathrm{~s}$, annealing temperature for $30 \mathrm{~s}, 72^{\circ} \mathrm{C}$ for $1 \mathrm{~min}$, and a final extension at $72{ }^{\circ} \mathrm{C}$ for $30 \mathrm{~min}$. We combined amplified products with a fluorescent size standard prior to running on an $\mathrm{ABI}$ 3730 (Applied Biosystems) at the Nevada Genomics Center. We identified allele sizes using GeneMarker software v1.85 (SoftGenetics). To confirm allele calls, we generated duplicate genotypes for $30 \%$ of the individuals at each locus. 
To identify the number of genetic clusters represented in these data without imposing prior spatial information, we used a Bayesian assignment approach as implemented in the program STRUCTURE ver. 2.3.4 (Pritchard et al. 2000, Falush et al. 2003). We performed 10 independent Markov chain Monte Carlo (MCMC) sampling runs with 100,000 burn-in steps and 1,000,000 search steps for each $\mathrm{K}$ from $\mathrm{K}=1$ to 20 . We used an admixture model, correlated allele frequencies, and $\lambda=1$. We identified the most probable number of clusters based on the rate of change in log probability of the data over successive $\mathrm{K}$ values $(\Delta \mathrm{K})$ as suggested by Evanno et al. (2005). This analysis first identifies the optimal number of genetic clusters that best describe the variation held in the data set, then assigns individuals to one or more of these genetic clusters. Each individual is assigned to at least one genetic cluster, though individuals can have partial assignment to more than one genetic cluster, suggesting hybrid or admixed ancestry. Despite having a priori knowledge of the genetic identification of the samples included in Bell and Matocq (2011), we ran all samples without locality or putative species identification in order to test consistency of the analyses across the 2 studies.

To further distinguish individuals of hybrid origin, we used the software NewHybrids 1.1 beta 3 (Anderson and Thompson 2002) to assign individuals to 1 of 6 genotypic classes (pure round-tailed ground squirrel, backcross to round-tailed ground squirrel, F1, F2, backcross to Mohave ground squirrel, and pure Mohave ground squirrel). We ran 3 independent MCMC chains with random starting points and Jeffreys-type priors for allele frequencies and mixing proportion for 2,000,000 sweeps for each chain after an initial burn-in of $1,000,000$ sweeps.

\section{REsults}

\section{Historic Range of the Mohave Ground Squirrel}

The California Department of Fish and Wildlife (California Department of Fish and Game prior to 1 January 2013) first provided a range map for the Mohave ground squirrel in its 1980 biennial report on the status of state-listed species (CDFG 1980). This official map was revised in 1992 as a result of advice from the department's Mohave Ground Squirrel Working Group. The revised map was included in an official status review prepared by Gustafson (1993). It showed the eastern boundary of the Mohave ground squirrel range as passing through the Barstow area, then southwest and south along the course of the Mojave River.

The 1993 location of the eastern boundary of the Mohave ground squirrel range in the Barstow area was based upon a total of 29 records in the CNDDB, the earliest of these dating from trapping surveys conducted in 1975 and 1977. Figure 2 shows the locations of these records in relation to Barstow. There were a number of occurrences north of Barstow on Coolgardie Mesa and in Superior Valley, with 2 others along Ft. Irwin Road (Wessman 1977). There were 8 CNDDB records to the west of Barstow from 1975 to 1988 , including 5 near Harper Lake and 3 along State Route 58. Mohave ground squirrels were also reported in the CNDDB as having been collected in 1981 at a location west of Coyote Dry Lake and at another site east of Daggett (Hafner and Yates 1983). The CNDDB listed 4 occurrences in Barstow itself dating from 1982 and 1993; these were based upon visual and auditory detections only. Finally, Mohave ground squirrels were observed in 1990 at a site about $3 \mathrm{~km}(2 \mathrm{mi})$ north of Lenwood (approximately $10 \mathrm{~km}$ west of Barstow) (CNDDB Occ. No. 277).

\section{New Evidence Concerning the Range Boundary}

The placement of the Mohave ground squirrel range boundary in the Barstow area has generally been accepted in recent literature (Leitner 2008). However, more recent evidence suggests that this boundary placement may not accurately reflect the current distributional limits of the species in this area.

First, 5 of the CNDDB occurrences shown in Fig. 2 have recently been removed from the Mohave ground squirrel database. These include 3 visual and auditory detections made within the city of Barstow in 1993. The original observer concluded that it was not possible to determine the species identity with certainty because of the similarity in physical appearance and vocalizations between Mohave and round-tailed ground squirrels (D. LaBerteaux personal communication). The 1981 Mohave ground squirrel CNDDB occurrences near 


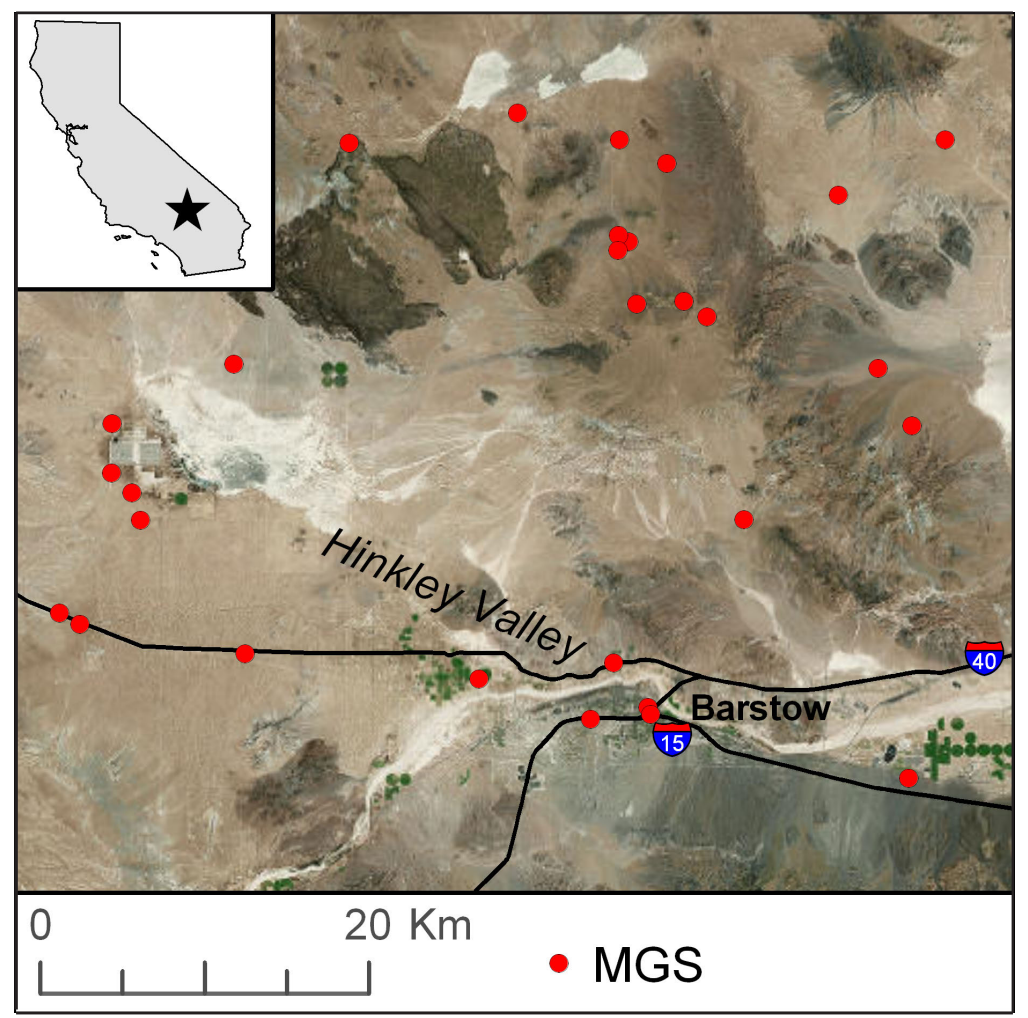

Fig. 2. Geographic distribution of Mohave ground squirrel records in the Barstow area from 1975 to 1993 based on the California Natural Diversity Database (CNDDB).

Coyote Dry Lake and Daggett were identified as erroneous (D. Hafner, personal communication), because the original report clearly identified these as round-tailed ground squirrel records (Hafner and Yates 1983). There were only 2 other Mohave ground squirrel CNDDB records in the Barstow area prior to the 1993 designation of the range boundary. In 1982 a Mohave ground squirrel was detected in Barstow just north of the Mojave River, and in 1990 there were reported observations of the species north of Lenwood.

Second, surveys using live-trapping and trail cameras have yielded many new Mohave ground squirrel detections since 1993. Figure 3 shows these newer, well-documented occurrences along with other records dating back to 1975. There is a clear geographic pattern, with the great majority of occurrences well to the north and west of Barstow. The 3 remaining records from the Barstow area are all based upon visual observations. These include the 1982 sighting in Barstow, the 1990 observa- tions north of Lenwood, and a visual record in 2005 about $6 \mathrm{~km}$ (4 miles) south of Barstow near the municipal landfill. In none of these cases were specimens actually trapped and examined, so it is difficult to be certain of the accuracy of the species identification.

When the Mohave ground squirrel range boundary was originally proposed to include the Barstow area, there was no consideration of distributional records of the round-tailed ground squirrel. Examination of museum records indicates that 4 round-tailed ground squirrel specimens are known from Barstow and vicinity, dating from 1914 to 1966. Wessman (1977) reported trapping round-tailed ground squirrels in the vicinity of Coyote Dry Lake and at a site near Hinkley. Round-tailed ground squirrels were recorded in 1981 by Hafner and Yates (1983) at 3 locations east of Barstow. During the period 2006-2009, there were a number of trapping surveys carried out in the Barstow area. These studies resulted in many captures of round-tailed ground 


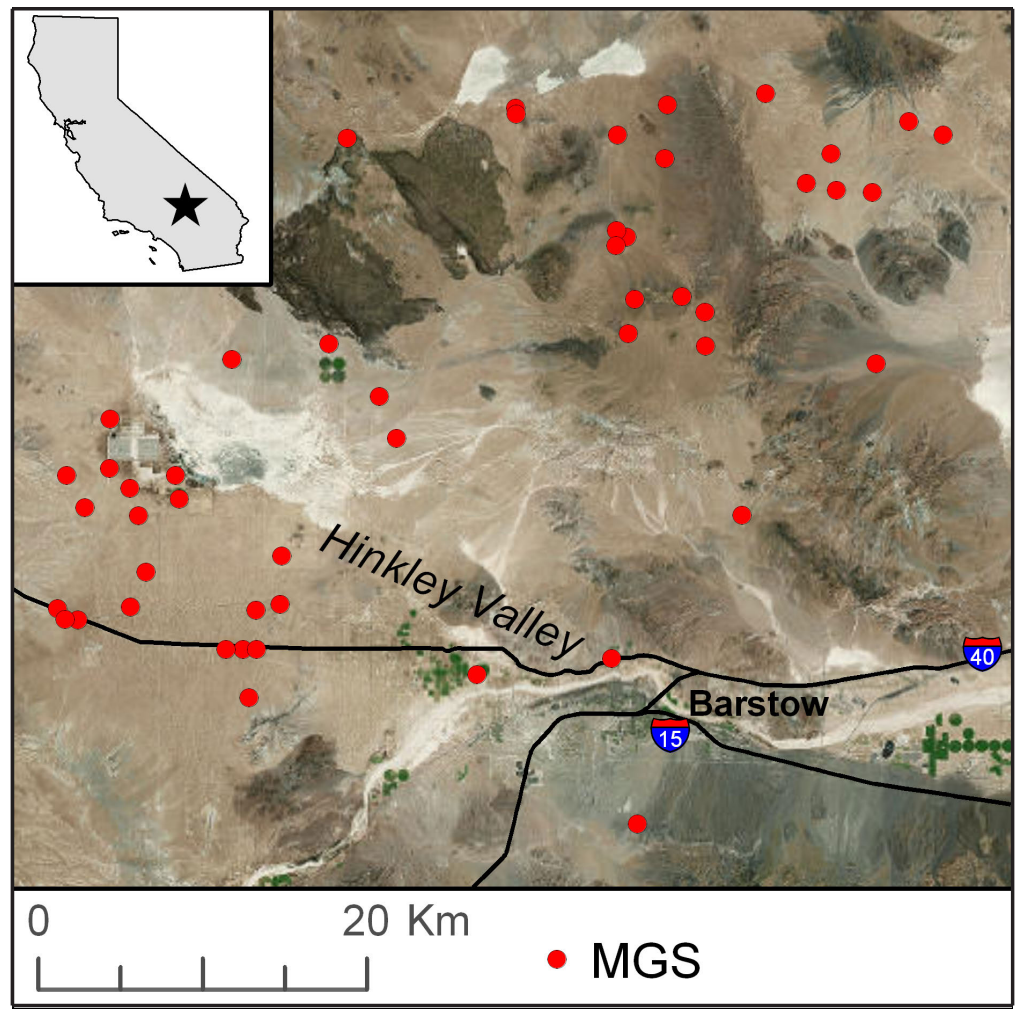

Fig. 3. Geographic distribution of Mohave ground squirrel records in the Barstow area from 1975 to 2014 based on multiple sources (see methods).

squirrels throughout this region, from Hinkley and Hodge east to Daggett. In attempting to accurately define the current range boundary, it is important to focus on data from trapping studies in which external diagnostic features could be closely examined. Figure 4 presents the geographic distribution of Mohave and round-tailed ground squirrel records through 2009 based upon trapping studies in which more reliable identification could be obtained. This figure shows that round-tailed ground squirrel records extend west from Barstow and the Mojave River into the Hinkley Valley.

\section{Genetic Analyses}

Genotypes generated during this study from the subset of individuals included in Bell and Matocq (2011) were consistent with the original genotypes. This suggests high repeatability of our lab methodology and consistency between the studies. All individuals expected to be round-tailed ground squirrels or Mohave ground squirrels from the previ- ous study were confirmed based on the new analysis. Table 1 shows the number of samples genotyped from each region and the number of individuals of each type that were recorded.

In the analysis of unknown samples from recent collections in the Hinkley area, we uncovered genetically pure Mohave ground squirrels and round-tailed ground squirrels, as well as hybrid specimens. In the vicinity of Hinkley we found evidence of Mohave ground squirrels and round-tailed ground squirrels occurring in close proximity to one another; there was also evidence of hybridization. Individuals with genomic compositions (q values) greater than $90 \%$ from one taxon or the other were considered genetically "pure." The vast majority of individuals had q values $>0.97$ for either round-tailed ground squirrel or Mohave ground squirrel, which we took as unambiguous assignment to either pure parental type. However, our structure analysis identified 2 individuals as hybrids $(\mathrm{q}<0.90)$ with a high degree of confidence (i.e., 95\% credibility 


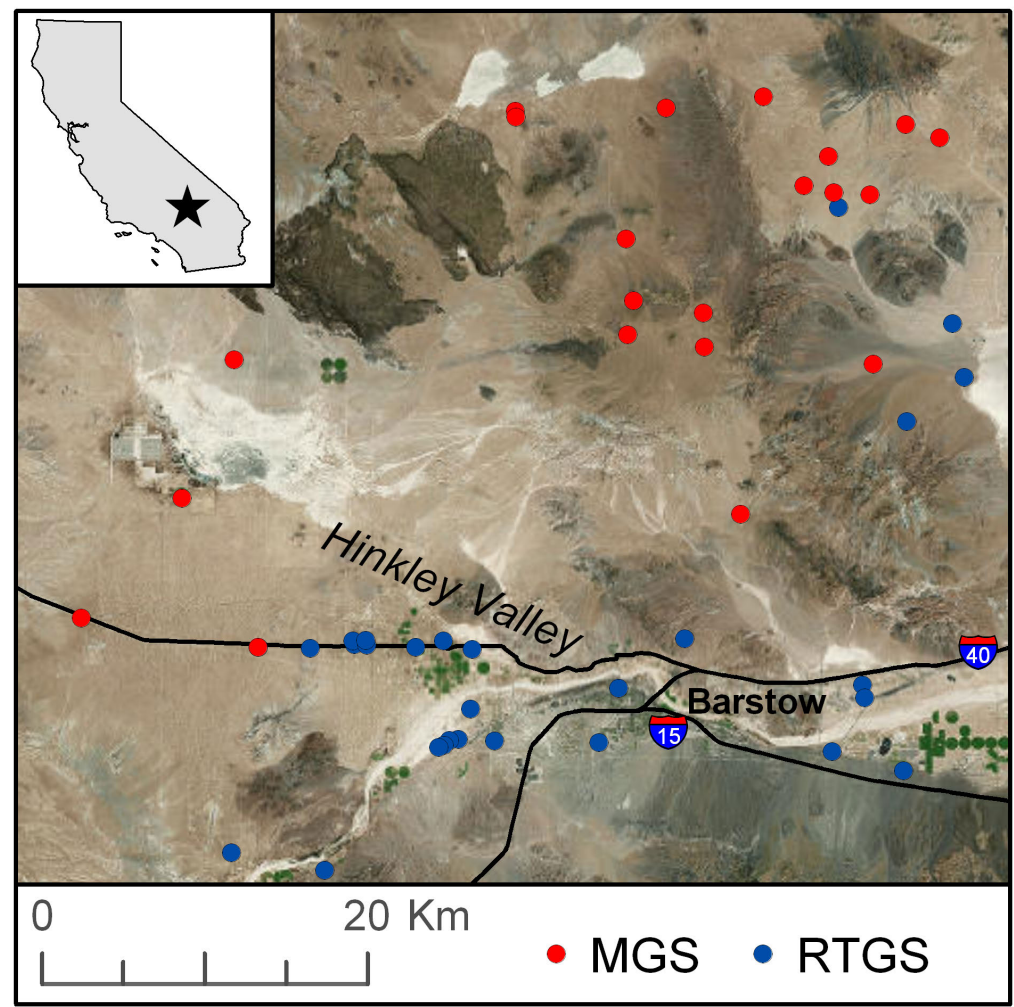

Fig. 4. Geographic distribution of Mohave ground squirrel (MGS) and round-tailed ground (RTGS) squirrel trapping records in the Barstow area from 1914 to 2009.

TABLE 1. Mohave ground squirrel (MGS) and round-tailed ground squirrel (RTGS) genetic samples analyzed in this study by general locality. The total number of individuals examined $(\mathrm{N})$ is shown for each locality. Each individual is listed in the genetic class to which it was assigned in a NewHybrids analysis (pure RTGS or MGS, first or second generation hybrid [F1/F2], backcross [BC] to either parental class, or uncertain assignment). AFB = Air Force Base, WEA = Western Expansion Area.

\begin{tabular}{|c|c|c|c|c|c|c|c|}
\hline General location & $\mathrm{N}$ & RTGS & MGS & $\mathrm{F} 1 / \mathrm{F} 2$ & BC-RTGS & BC-MGS & Uncertain \\
\hline Boron & 15 & & 15 & & & & \\
\hline Coolgardie Mesa & 7 & & 7 & & & & \\
\hline Edwards AFB & 16 & & 16 & & & & \\
\hline Fremont Peak & 5 & & 5 & & & & \\
\hline Ft. Irwin WEA & 8 & & 8 & & & & \\
\hline Hinkley & 55 & 31 & 18 & 2 & & 3 & 1 \\
\hline Kramer Junction & 21 & & 21 & & & & \\
\hline
\end{tabular}

intervals not encompassing 0 ). The same analysis identified another 3 individuals as probable hybrids based on their mean genomic composition $(q<0.90)$, but with a lower level of confidence given that their $95 \%$ credibility intervals encompassed 0 and 1 , suggesting that at least some runs found them to be pure individuals. Our NewHybrids analysis confirmed the hybrid status of the same 5 individuals found in the structure analysis and was able to classify these individuals into their genotypic classes (i.e., first generation hybrid versus second generation and further backcrosses to either parental type). NewHybrids analysis identified MGS765 and MGS777 as second generation hybrids, suggesting that these individuals were the offspring of first generation animals that were the outcome of a direct intercross between a pure round-tailed ground squirrel and a 


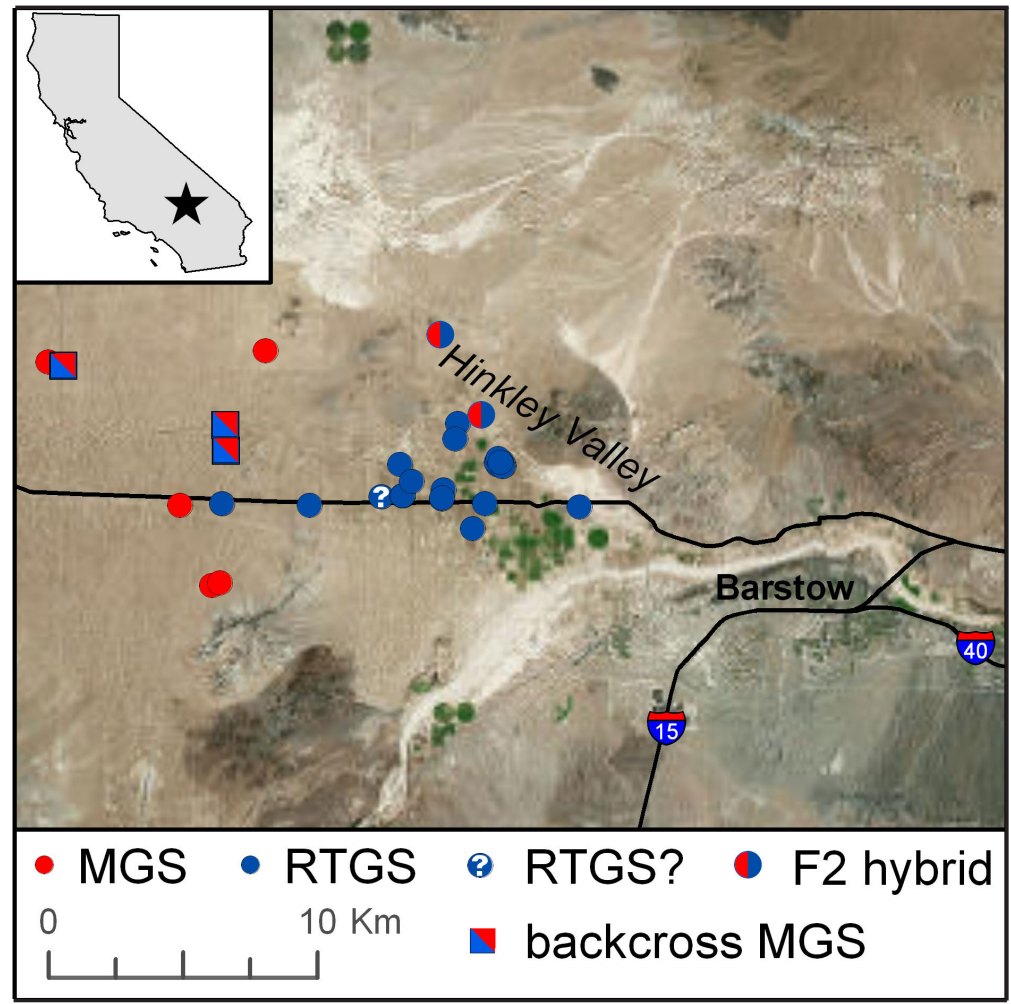

Fig. 5. Geographic distribution of Mohave ground squirrels (MGS), round-tailed ground squirrels (RTGS), and hybrids (F2 hybrid, backcross MGS) in the Hinkley area based on genetic analyses.

Mohave ground squirrel. MGS784, MGS785, and MGS854 were identified as backcross Mohave ground squirrels. Finally, a single sample, GS601, could not be classified by NewHybrids because of partial probability in multiple classes, namely pure round-tailed ground squirrel and backcross round-tailed ground squirrel. The STRUCTURE run showed a mean genomic composition of 0.916 round-tailed ground squirrel, suggesting that this animal may have had admixed ancestry, although it was slightly above our $90 \%$ threshold cutoff value.

The majority of individuals from the agricultural areas of the Hinkley Valley were classified as round-tailed ground squirrels (Fig. 5). Two samples (MGS765 and MGS777) collected in the northern Hinkley area were of mixed ancestry, and another sample (GS601) that was found farther south near SR58 may have had mixed ancestry. A number of individuals from the desert habitat west of Hinkley were genotyped as pure Mohave ground squirrels. Nevertheless, there were 3 animals (MGS784, MGS785, and MGS854) from that region that were classified as backcross Mohave ground squirrels, indicating some roundtailed ground squirrel genetic contribution in their ancestry.

\section{DisCUSSION}

Recent data strongly indicate that the eastern boundary of the Mohave ground squirrel range lies in the vicinity of Barstow well to the west of the Mojave River. The only recent Mohave ground squirrel record east of the Mojave River is from a visual observation in 2005 near the Barstow landfill that has not been confirmed by trapping. Two older Mohave ground squirrel records near Lenwood and Barstow were also based on visual observations, but these sightings have not been confirmed.

It seems clear from both trapping data and genetic analysis that the dominant Xerospermophilus species in the Hinkley Valley is the 
round-tailed ground squirrel. The earliest trapping record of this species in the area dates back to 1977, long after the native desert habitat there was converted to irrigated agricultural land. Because round-tailed ground squirrels appear to be more tolerant of disturbance, it is possible that they largely replaced an original Mohave ground squirrel population after the land was converted. Although we found no evidence of genetically pure Mohave ground squirrels in the Hinkley Valley, there is reason to believe that they are still present. We found 2 specimens that were classified as F2 hybrids, indicating that they had significant Mohave ground squirrel ancestry. These individuals were captured in desert scrub habitat to the north of areas converted for agricultural production. It is noteworthy that when these animals were captured, they were identified as typical round-tailed ground squirrels based upon their external characteristics. Another individual from the western edge of the Hinkley Valley also showed evidence of possible Mohave ground squirrel genetic ancestry.

Well to the west of Hinkley Valley in relatively undisturbed desert habitat, Mohave ground squirrels are the dominant species. Nevertheless, we found evidence that at least some round-tailed ground squirrels may be present here. Three individuals that had all the expected external features of typical Mohave ground squirrels showed genetic evidence of ancestry from round-tailed ground squirrels. Camera studies and live-trapping in this region have also revealed 2 cases in which both species were present simultaneously (Leitner 2008, 2015).

While the exact ancestry or detailed pedigree of the individuals sampled for this study cannot be inferred from these analyses, our results confirm that pure parental types are in close proximity, that hybridization does occasionally occur, that at least some hybrids are fertile, and that backcrossing occurs in both parental directions. The frequency of hybridization, its spatial distribution, and the ecological or demographic factors that contribute to hybridization require further investigation.

Our study highlights the importance of combining intensive field surveys with genetic analyses to more completely understand the range limits of threatened or endangered species. In particular, when threatened or endangered species come into proximity of the range of conspecifics with which they may hybridize, it is particularly critical to use genetic data to confirm field identifications. The mixture of otherwise species-specific external morphological traits that can exist in hybrids makes field-based species identification particularly challenging. Moreover, backcrossed individuals may exhibit the key external traits of only one parental species, leading to underestimation of hybridization. In sum, hybridization and other ecological interactions of Mohave ground squirrels with round-tailed ground squirrels warrant further investigation to understand how these interactions impact the current distribution of the Mohave ground squirrel and the capacity of this species to respond to ongoing land use and environmental change.

\section{ACKNOWLEDGMENTS}

We thank W.J. Vanherweg for sharing the results of his field surveys in Hinkley Valley and for providing a number of tissue samples for genetic analysis. We are grateful to others who provided data on Xerospermophilus occurrences and contributed tissue samples, including S. Dayton, D. LaBerteaux, E. LaRue, D. Mitchell, and L. Simone. We thank T. Dilts for assistance with figures. Funding for this analysis was provided by Pacific Gas \& Electric Company through contracts with $\mathrm{CH} 2 \mathrm{M}$ Hill to the University of Nevada, Reno, and P. Leitner.

\section{Literature Cited}

Anderson, E.C., And E.A. Thompson. 2002. A modelbased method for identifying species hybrids using multilocus genetic data. Genetics 160:1217-1229.

Bell, K.C., AND M.D. MatocQ. 2010. Development and characterization of polymorphic microsatellite loci in the Mohave ground squirrel (Xerospermophilus mohavensis). Conservation Genetics Resources 2: 197-199.

Bell, K.C., AND M.D. MatocQ. 2011. Regional genetic subdivision in the Mohave ground squirrel: evidence of historic isolation and ongoing connectivity in a Mojave Desert endemic. Animal Conservation 14:371-381.

[BLM] Bureau of Land Management. 2005. Final environmental impact report and statement for the West Mojave Plan. Bureau of Land Management, California Desert District, Moreno Valley, CA.

[CDFG] California Department of Fish and Game. 1980. At the crossroads: a report on the status of California's endangered and rare fish and wildlife, Fifth Biennial Report. California Department of Fish and Game, Sacramento, CA. 147 pp. 
Evanno, G., S. Regnaut, and J. Goudet. 2005. Detecting the number of clusters of individuals using the software STRUCTURE: a simulation study. Molecular Ecology 14:2611-2620.

Falush, D., M. Stephens, and J.K. Pritchard. 2003. Inference of population structure using multilocus genotype data: linked loci and correlated allele frequencies. Genetics 164:1567-1587.

Garner, A., J.L. Rachlow, and L.P. Waits. 2005. Genetic diversity and population divergence in fragmented habitats: conservation of Idaho ground squirrels. Conservation Genetics 6:759-774.

Gustafson, J.R. 1993. A status review of the Mohave ground squirrel (Spermophilus mohavensis). Nongame Bird and Mammal Report 93-99, State of California. Department of Fish and Game, Sacramento, CA. 104 pp. + appendixes.

HafNer, D.J., AND T.L. Yates. 1983. Systematic status of the Mojave ground squirrel, Spermophilus mohavensis (subgenus Xerospermophilus). Journal of Mammalogy 64:397-404.

Leitner, P. 2008. Current status of the Mohave ground squirrel. Transactions of the Western Section of The Wildlife Society 44:11-29.

Leitner, P. 2015. Current status of the Mohave ground squirrel (Xerospermophilus mohavensis): a five-year update (2008-2012). Western Wildlife 2:9-22.
May, B., T.A. Gavin, P.W. Sherman, and T.M. Korves. 1997. Characterization of microsatellite loci in the northern Idaho ground squirrel, Spermophilus brunneus brunneus. Molecular Ecology 6:399-400.

Pritchard, J.K., M. Stephens, and P. Donnelly. 2000. Inference of population structure using multilocus genotype data. Genetics 155:945-959.

Stevens, S., J. Coffin, and C. Strobeck. 1997. Microsatellite loci in Columbian ground squirrels, Spermophilus columbianus. Molecular Ecology 6:493-495.

VanherweG, W.J. 2012. Pacific Gas \& Electric Hinkley Ground Water Remediation Project, Mohave/roundtailed ground squirrel trapping results. Prepared for CH2M Hill, Inc., Sacramento, CA. 18 pp.

Vanherweg, W.J. 2013. Pacific Gas \& Electric Hinkley Ground Water Remediation Project, Protocol Mohave/ round-tailed ground squirrel trapping results. Prepared for CH2M Hill, Inc., Sacramento, CA. 42 pp.

Wessman, E.V. 1977. The distribution and habitat preferences of the Mohave ground squirrel in the southeastern portion of its range. California Department of Fish and Game, Wildlife Management Branch Administrative Report 77-5. 15 pp. + appendixes.

Received 10 April 2016 Accepted 2 February 2017 Published online 7 July 2017 